\title{
Navigating a just and inclusive path towards sustainable oceans*
}

\author{
Nathan J. Bennett ${ }^{1,2,3}$
}

\author{
Affiliations: \\ 1. Institute for Resources, Environment and Sustainability, University of British Columbia, Vancouver, \\ BC, Canada \\ 2. University of Nice Sophia Antipolis, Nice, France \\ 3. Center for Ocean Solutions, Stanford University, Monterrey, CA, USA
}

Contact: nathan.bennett@ubc.ca

\begin{abstract}
The ocean is the next frontier for many conservation and development activities. Growth in marine protected areas, fisheries management, the blue economy, and marine spatial planning initiatives are occurring both within and beyond national jurisdictions. This mounting activity has coincided with increasing concerns about sustainability and international attention to ocean governance. Yet, despite growing concerns about exclusionary decision-making processes and social injustices, there remains inadequate attention to issues of social justice and inclusion in ocean science, management, governance and funding. In a rapidly changing and progressively busier ocean, we need to learn from past mistakes and identify ways to navigate a just and inclusive path towards sustainability. Proactive attention to inclusive decision-making and social justice is needed across key ocean policy realms including marine conservation, fisheries management, marine spatial planning, the blue economy, climate adaptation and global ocean governance for both ethical and instrumental reasons. This discussion paper aims to stimulate greater engagement with these critical topics. It is a call to action for ocean-focused researchers, policy-makers, managers, practitioners, and funders.
\end{abstract}

Keywords: ocean governance, justice and equity, inclusion and participation, marine conservation, fisheries management, blue economy, marine spatial planning

\section{Governance of the frontier ocean}

The ocean is often viewed as the next frontier for many conservation and development activities. Evidence of increasing activity is apparent, for example, in a) the rapid proliferation of and international agreements to increase marine protected areas (MPAs) globally [1], b) expanding global fisheries combined with complexity in fisheries management [2-4], c) the current and forecasted growth of the "Blue Economy" which aims to capitalize on living and non-living marine resources [5-7], and d) an upsurge in marine spatial planning (MSP) processes [8,9]. These activities are ramping up not just within national jurisdictions - i.e., the Exclusive Economic Zones (EEZ) of countries as established under the United Nations Convention on the Law of the Sea (UNCLOS) - but also in international waters $[3,10,11]$.

Intensifying activity in the oceans has coincided with growing attention globally to the sustainable management and governance of the oceans [12]. For example, the international community agreed to protect $10 \%$ of the oceans in MPAs under the Convention on Biological Diversity in 2010. In

\footnotetext{
* This is an article pre-print. Please cite as follows: Bennett, N.J. (2018). Navigating a just and inclusive path towards sustainable oceans. Marine Policy. DOI: 10.1016/j.marpol.2018.06.001. Link: https://www.sciencedirect.com/science/article/pii/S0308597X18301465
} 
2012, the United Nations (UN) Conference on Sustainable Development (Rio+20) identified the oceans as one of seven priority areas for sustainable development and called for immediate action on depleting fish stocks, destruction of habitats, alien invasive species, conserving marine biodiversity, ocean acidification and climate change [13]. Then, in 2015, the United Nations adopted a Sustainable Development Goal (SDG 14 - Life Below Water) that specifically focuses on the oceans. Global ocean governance discussions have also increasingly focused on international waters. For example, the UN General Assembly adopted a resolution in 2017 (i.e., 69/292) to develop an instrument to protect marine biological diversity in areas beyond national jurisdiction (ABNJ).

The number of global ocean-focused conferences is also rapidly increasing - as is the timbre of urgency to manage and govern the oceans sustainably. In 2017 alone, the United Nations hosted the $1^{\text {st }}$ The Ocean Conference (New York, June 2017), the Economist hosted the $4^{\text {th }}$ World Ocean Summit (Bali, Feb. 2017), the International Union for the Conservation of Nature (IUCN) will host the $4^{\text {th }}$ International Marine Protected Areas Congress (Chile, Sept. 2017), the European Union hosted the $4^{\text {th }}$ annual global Our Oceans Conference (Malta, Oct. 2017) and the World Ocean Council hosted the Sustainable Ocean Summit (Halifax, Dec 2017). While historically the focus of these conferences has been on marine conservation, there is increasing emphasis on the growth, and sustainable development, of the blue economy. This was a central focus of the $5^{\text {th }}$ World Ocean Summit, hosted by The Economist and the Mexican Government, in Mexico in March 2018 [14]. The marine science community is also rising to meet the challenges posed by a busy and changing ocean - with global research networks (such as Future Earth and the Earth Systems Governance project) hosting or launching ocean-focused research clusters (See [15-18]) and the recent announcement by UNESCO that 2021-2030 will be the Decade of Ocean Science for Sustainable Development [19,20].

Yet, across the ocean governance, management, science and funding community, greater attention must be paid to issues related to social justice and inclusion in the pursuit of sustainable oceans. In particular, these considerations need to be better taken into account across key ocean policy domains including marine conservation, fisheries management, marine spatial planning, the blue economy, climate adaptation and global ocean governance. The aim of this discussion paper is to stimulate further engagement with these critical topics. To that end, this paper is laid out as follows. First, it briefly introduces the types of injustices and exclusions that can occur in the oceans. Next, it clarifies the ethical and instrumental rationales for a greater focus on inclusive governance processes and socially just outcomes. The following section emphasizes the role of the applied social sciences in developing robust and evidence-based solutions. In conclusion, the paper urges the ocean science, governance, management, practitioner and funding communities to further engage through applied social science research efforts, during national and global policy discussions and through supporting practical actions to proactively address issues related to exclusion and injustice in ocean policies, programs and management.

\section{Exclusions and injustices in ocean management and governance}

As the aforementioned ocean-related activities and global policy discussions have mounted, so too has the evidence of past and ongoing exclusionary decision-making processes and social injustices in some initiatives and locations. For example, the establishment of MPAs has rapidly increased around the world to meet global targets, which has coincided with critical accounts and research documenting lack of inclusion, failure to consider local people's needs and livelihoods, dispossession of areas and resources, and even human rights issues in some initiatives [21-27]. Some authors and civil society 
organizations have gone so far as to question whether some MPAs are a form of "ocean grabbing" [26,28-31], a term that refers to "the dispossession or appropriation of use, control or access to ocean space or resources from prior resource users, rights holders or inhabitants...through inappropriate governance processes and might employ acts that undermine human security or livelihoods or produce impacts that impair social-ecological well-being" [30]. Fisheries allocation decisions and management practices have often been critiqued as well, for failing to take into account the rights, needs and livelihoods of small-scale fishers and coastal communities [32-35]. For example, the implementation of Individual Transferable Quotas (ITQs) in Canadian and Icelandic fisheries has led to the consolidation of licenses, control by corporate interests and loss of jobs and economic benefits for coastal communities [36-39]. A critical missing element in many fisheries management decisions has been the lack of consideration of equity, or the distributional impacts of decisions, over both the short and long term [40,41]. This omission can produce unintended social consequences such as undermining the rights and access, historical tenure, traditional livelihoods and the food security needs of small-scale fishers and coastal communities [42-44]. By now, we are also well aware of the widespread "slavery scandals" that have infiltrated global seafood supply chains [45]. This repugnant problem, however, only represents a small part of the extensive labor and human rights issues (e.g., evictions, unsafe working conditions, child labor, etc.) in global fisheries [46,47].

The social challenges and implications of both marine spatial planning (MSP) and blue economy developments are only starting to become apparent. However, the topic of who is actually included in and who is benefiting from or bearing the burdens of these idealized MSP processes is under increasing scrutiny [48-50]. This is not surprising as a recent review of coastal and ocean planning processes showed that less than $50 \%$ included social data and only $10.8 \%$ of social data were spatially characterized [51]. Similar questions are being asked about social inclusion and the impacts of the blue economy - including in aquaculture, exploration and mining, oil and gas extraction, energy development, bio-prospecting, marine tourism, and carbon markets [6,12,52]. Where the assumption of some proponents of the blue economy seems to be that development will lead to net social and economic good [53], past research has shown how the economic benefits of blue economic development may fail to accrue to local people, and those that do are often shared inequitably, and also that the social and environmental burdens (e.g., waste, water shortages, pollution) may be considerable for nearby communities [54-61]. One reason for the inequitable distribution of benefits and costs may be lack of genuine consultation or engagement in decisions [55,58]. Keen et al. [54], for example, illustrate that key components related to community engagement and gender equity were missing in blue economic development in the Pacific Islands. A number of authors have expressed concern about the progressive capitalization, privatization and enclosure of the ocean's resources and spaces that is occurring via the growth of the blue economy and MSP [37,50,52,62,63].

A further marine and coastal policy challenge where local people can be marginalized is in climate change adaptation. Climate change has numerous direct and indirect impacts on fishers and coastal communities - for example, through causing declines and shifting distributions in fisheries, rising sea levels, flooding, saltwater intrusion, erosion and increased storm events [64-67]. As a result, there has been significant attention to the adaptation of coastal cities, rural communities, indigenous communities, as well as small-scale fishers. Problematically, climate adaptation planning processes can exclude local perspectives from decision-making and produce adaptations that further marginalize certain racial, socio-economic, or already vulnerable groups [68-70]. Furthermore, when environmental management or marine conservation are employed as adaptations, this can place additional burdens onto coastal communities or groups that are already suffering the impacts of climate change and undermine local resilience [71]. 
The vast majority of the ocean-related social justice issues previously documented in the academic literature have been focused on local and national scale issues. However, as activities and pressure in the high seas mounts, multi-lateral and global issues related to equitable allocation in transboundary fisheries, justice in benefits from the harvest of living and non-living resources in areas beyond national jurisdiction (ABNJ), and good governance (e.g., transparency, accountability, participation in decision-making) in global decision-making processes are also coming to the fore $[10,11,72,73]$. Thus, while thinking at this scale might be challenging, inclusive governance and social justice are also salient concerns in efforts to sustainably govern the global oceans.

The review and examples presented above are neither comprehensive nor representative. What these scenarios highlight, however, is the types of exclusions and injustices that have emerged in the past and that may continue to occur in future conservation, management and development activities in the oceans. These issues should be avoided for the reasons highlighted below.

\section{The rationale for just and inclusive ocean governance}

This paper identifies social justice and inclusion as key issues that need to be addressed in ocean science and governance globally. Yet some proponents of actions to promote sustainability in the oceans may wonder whether a greater focus on justice and inclusion is warranted. As discussed below, it is important for both ethical and instrumental reasons.

First, a renewed and invigorated focus on justice and inclusion in the oceans might be considered the right thing to do: local communities, traditional resource users, and indigenous people should be included in decision-making and benefit from adjacent resources. Adding legitimacy to this claim is the fact that social norms (such as rights, justice, equity, etc.) and good governance principles (such as participation, transparency, accountability, etc.) are often codified in guidance documents and/or enshrined in international policies for different areas of marine policy. For example, Aichi Target 11 of the Convention on Biological Diversity specifies that networks of marine protected areas (MPAs) need to be both "effectively and equitably managed" [74]. The academic literature suggests that equitable management entails that: a) the rights, culture and knowledge of local stakeholders and communities are recognized, b) that procedures build on the ideals of good governance - such as participation, inclusion, transparency, access to justice, accountability, and Free, Prior and Informed Consent (FPIC), and c) that the benefits and burdens of conservation are mitigated and managed [21,75-78]. The social mandate of fisheries is well-established in both national and international policies $[46,79,80]$. Furthermore, the United Nations FAO Voluntary Guidelines for Securing Sustainable Small-Scale Fisheries, FAO Voluntary Guidelines on the Responsible Governance of Tenure, FAO Code of Conduct for Responsible Fisheries, and the ILO Work in Fishing Convention establish the importance of taking human rights, well-being, livelihoods, tenure, food security, working welfare, and participation into account in fisheries management [32,81-83]. The aim of MSP, according to the definitive manual by Ehler and Douvere [84], is balancing social, economic and environmental objectives through participation with stakeholders (see also [8]). The blue economy, on the other hand, still exists in somewhat of a social policy vacuum - though the concept as put forward in the "Blue Economy Concept Paper" after Rio+20 was that it build on Green Economy ideals of environmental sustainability, sustained economic growth, enhanced social inclusion, improved human welfare and social equity [85]. James Alex Michel, President of the Republic of the Seychelles, also took up these ideals in his 2017 book "Rethinking the oceans: Towards the blue economy" [86] as did the World Bank and United Nations report "The 
Potential of the Blue Economy" [7]. At the time of writing the Commonwealth Secretariat is working to develop a "Blue Charter" - building on the principles contained in the Commonwealth Charter including environmental protection, good governance, human rights and justice $[87,88]$ - that might provide an important model for global policy development related to the blue economy. At the level of global ocean governance, the United Nations Convention on the Law of the Sea (UNCLOS) is the main overarching framework that aims to conserve resources and protect the marine environment, while providing for efficient and equitable use and coordinated decision-making from global to regional to national levels. Finally, the ocean policies mentioned here are guided by international soft laws and conventions, which are not ocean-focused, with similar commitments to norms of justice and inclusion. This includes, for example, the UN Universal Declaration of Human Rights, the UN Declaration on the Rights of Indigenous Peoples, the UNECE Aarhus Convention on Access to Information, Public Participation in Decision-Making and Access to Justice in Environmental Matters, and the Sustainable Development Goals [89-92].

Furthermore, inclusion and justice can be instrumental to success. Social blunders - i.e., lack of consideration or inclusion in decision-making and perceived or real inequities - may also undermine the ocean sustainability agenda. For example, ignoring the voices and concerns of local people and resource users can lead to local community opposition to or civil society backlash against marine protected areas [24,27,93], blue carbon initiatives [29], or sustainable blue economy developments [52]. The International Collective in Support of Fisherworkers (ICSF) and World Forum of Fisherpeople (WFF), for example, have been vocal in their opposition to mangrove conservation through Blue Carbon market investments and also to other forms of blue economy development. In their view, these initiatives are producing coastal land and ocean grabs which exclude small-scale fishers from their lands, livelihoods and produce more harms than benefits $[26,94,95]$. Critical and adversarial perspectives can also enter into national and global policy dialogues via academic publications [21,96], debates in popular media [94,97], high profile court cases [98,99], or global policy conferences [22]. Indeed, it is both understandable and justifiable that local and global opposition to efforts to promote sustainability will continue to arise when the voices, rights, and needs of local people and coastal communities are not taken into account. Yet, these critiques need not inspire antagonism and entrenchment within different policy camps as they often do. Conflict can be productive when warnings from civil society are heeded, lessons are learned through research and dialogue, and improvements are made to decision-making processes or management actions through deliberations and adaptive governance. Proactively addressing social justice issues will enable the social license, long-term support, and durability of efforts to sustainably manage and govern the ocean.

\section{From issues to evidence-based solutions}

Research has a critical role to play in enabling more just conservation and development actions and more inclusive decision-making processes in the oceans [46,100]. Governments, managers, NGOs and funders aim to promote policies that are based on the best available scientific evidence to increase effectiveness and improve outcomes. However, many ocean-related policies, management practices and NGO programs are often motivated or guided only or primarily by evidence from the natural sciences. The human dimensions - social, cultural, economic, governance and health considerations - are often given less attention in decision-making and management [80,101,102]. Yet the marine environment is far from empty space - rather people live near, rely on, and are culturally and historically connected to the world's oceans and coasts. Neglecting to consider the human element in the world's peopled seas can lead to the types of unintended social consequences mentioned previously. The social sciences, in particular, can increase our understanding of the issues and aid in the development of solutions to 
address them.

First, the social sciences can be used to learn lessons from the past. While there has been extensive research on individual projects and locations (see citations above), there is a need for scaledup research efforts (e.g., systematic reviews, multiple case studies, meta-analyses) to better understand where, why and how past issues have emerged. Comparative analysis of successes and failures in how marine conservation, planning and development has impacted local populations and or included their perspectives and needs in decision-making processes could facilitate a better understanding of lessons learned and guide the development of best practices [21]. Much could also be drawn from examining the historical processes and impacts of similar activities (e.g., conservation, planning, enclosures, etc.) in the terrestrial realm. It would also be worthwhile to try to understand why justice and inclusion considerations have been missing in ocean governance.

Second, insights and approaches from the applied social sciences can help to develop solutions to address social and procedural issues. Indeed, the applied and solution-oriented social sciences have already advanced far ahead of the practice - with critical insights and novel approaches into how to better integrate human dimensions considerations into conservation, planning, fisheries and development processes being underutilized [103-107]. Important recent advances have been made into, for example, the incorporation of diverse socio-economic and cultural values in marine planning [103-105,108-110], the design and monitoring of equitable management of conservation initiatives [76,77,111], the monitoring and adaptive management of the social impacts of environmental management initiatives on human well-being, [112-115], the design of benefit sharing arrangements for marine and coastal development [107,116,117], approaches to consider equity and make triple-bottom line decisions in fisheries $[41,79,118,119]$, and the creation of inclusive and collaborative marine planning management and good governance processes [11,84,120-124]. These are just a few among many examples of how the applied social sciences can help to address the types of issues highlighted earlier. Additional targeted social science research projects could help to better understand the issues and develop robust and evidence-based solutions across different realms of ocean policy. While marine conservation and fisheries management will remain important topics of research, there is a need to increase attention to justice and inclusion in the blue economy, MSP and climate adaptation at all scales from local to global.

Finally, these advances in applied and solution-oriented research need to be complemented by efforts to ensure that insights and approaches to address these issues inform decision-making and management actions. Bridging the science-policy-practice gaps might be facilitated by: a) improving the communication of social science research insights, b) increasing the attention paid to practical application, c) enhancing collaboration in the production of knowledge and solutions at all scales, and d) promoting communities-of-practice and knowledge-action networks to advance both knowledge and practice [102,106,125-127]. First, efforts are needed to more clearly communicate the insights and implications of social science research to ocean-focused policy-makers and practitioners. While significant emphasis has been placed on the communication of natural science, more social scientists need training in communication and support with outreach efforts [106]. Second, further initiative and assistance is needed to move from high-level ideas, processes and frameworks to the development and implementation of practical tools, approaches and guidance documents to support on-the-ground implementation. Many of the ideas and frameworks emerging from the social sciences are still idealized and need to be field-tested and evaluated, prior to being developed into practical tool-kits and guidance documents for more broad application. Adequate funding will be essential to enable such efforts to move from research to the development of practical outputs and actions. Third, there is a need for much greater collaboration - amongst researchers, practitioners, stakeholders and policy-makers - in the 
production of both knowledge and solutions to ensure that they are grounded and practicable. This might be accomplished, for example, through team efforts such as action research projects focused on local marine conservation [128], knowledge co-production efforts to transform marine management [129] or solution-oriented think tanks to address pressing global policy issues [102]. Finally, support is needed for the further development of communities-of-practice (such as the Human Dimensions of Large-Scale Marine Protected Areas Community-of-Practice [102]) or knowledge-action networks (such as Future Earth Oceans [18]) to advance both knowledge and practice related to the human dimensions of different ocean policy domains. It is important that any such efforts are diverse - with representation from different geographies, ethnicities, genders, ages, etc. - and contains a broad knowledge base and skill set. Yet, such efforts to bridge the science-policy-practice gaps may not succeed without adequate political, practical and financial support for action.

\section{Prioritizing justice and inclusion in the pursuit of sustainable oceans}

Rather than dwell on past issues, this paper argues that more attention is needed to issues related to justice and inclusion across different realms of ocean policy including marine conservation, fisheries management, marine spatial planning, the blue economy, climate adaptation and global ocean governance processes. This is a call to action for the ocean science, management, governance and funding communities.

First, we can no longer afford to base marine conservation and management decisions on environmental science alone. The historical connection and continued reliance of people to most of the world's oceans increases the complexity of the challenges and points to the need for greater attention to social, cultural, economic and governance considerations in decision-making [102,130]. To ensure that they are not operating unawares, government agencies and non-governmental organizations working on the ground to implement different policies, programs or management actions in the marine and coastal environment would benefit from adequate capacity and funding to perform basic social science. Essential social science to inform just and inclusive marine policies, programs and management includes, for example, a) understanding the social context prior to implementing actions, b) forecasting the social implications of alternative management options or adaptation options, c) identifying mechanisms to mitigate or compensate for social impacts, d) monitoring and evaluating social impacts, e) adapting management actions and development activities to improve social outcomes, and f) understanding what constitutes culturally appropriate and socially acceptable governance structures and processes. More broadly, greater attention to the human dimensions is needed in global ocean science networks and the social sciences should be central to the purview of the UN Decade of Ocean Science 2021-2030 [19].

Second, justice and inclusion should be central considerations in national and global policy discussions related to the ocean. As governments and their agencies formulate laws, policies and management actions related to marine conservation, fisheries management, the blue economy, marine spatial planning and adaptation to climate change, procedural and distributional considerations ought to be taken into account to ensure alignment with the global commitments discussed earlier. This might include, for example, ensuring participation and inclusion of diverse perspectives in decision-making processes and understanding the social implications - both costs and benefits - of policies and management actions for coastal residents and other stakeholder groups. Global governance organizations focused on these ocean policy realms - including the International Union for the Conservation of Nature (IUCN), the Convention on Biological Diversity (CBD), the United Nations Educational, Scientific and 
Cultural Organization (UNESCO), the Food and Agricultural Organization (UN FAO), etc. - also have a duty and responsibility to ensure these issues are addressed in policy and practice. For example, these topics should be part of upcoming policy deliberations related to the achievement of Sustainable Development Goal 14 (Life Below Water), the protection of Biodiversity Beyond-National Jurisdiction (BBNJ), and the development of the Blue Economy. These venues provide important opportunities to advance the ocean sustainability agenda in a manner that is both just and inclusive.

Third, it is not just in research or policy - but in real-world programs and management practice where further attention is needed to: a) designing equitable and inclusive marine conservation initiatives; b) creating socially responsible and sustainable fisheries supply chains and management; c) ensuring that local people are included in, benefit from and are not unduly impacted by the blue economy; d) incorporating diverse stakeholders, perspectives and values in marine spatial planning; e) facilitating inclusive, transparent, accountable and just global ocean governance processes; and f) producing participatory and fair climate adaptations. Both knowledge of the issues as well as practical guidance, tools, and approaches are often lacking to help government decision-makers, on-the-ground managers, NGO practitioners and funders to effectively take these considerations into account. While priority action areas in each ocean policy realm really ought to be identified through rigorous social science research combined with participatory dialogues with experts and stakeholders, some initial thoughts on priority action areas are identified in Table 1. Initiating a working group of researchers and practitioners to further examine these topics would allow for the proactive and participatory identification of priority topics for further research and practical outputs and actions to address the issues.

Finally, the ocean funding community - including national and multi-lateral funding organizations (e.g, development aid agencies, development banks, World Bank, GEF, UNEP and FAO) large foundations (e.g., Moore, Packard, Oak, Bloomberg, Marisla, Pew, Walton, Waitt, etc. - see http://fundingtheocean.org) and funding collectives (e.g., Oceans 5) - need to ensure that they are advocating for policies and advancing programs that are socially responsible and that they are accountable to those implicated [21,131]. Both multi-lateral funding organizations and foundations also have an important role to play in proactively supporting more inclusive ocean governance processes, insight- and solution-oriented research, knowledge co-production and dissemination efforts, and practical actions and programs to address social justice issues.

\section{Conclusion}

Paying heed to social justice concerns does not preclude the importance of taking action to conserve and manage the marine environment and fisheries, as a sustainable and productive environment is also needed for food security, livelihoods, and a suite of economic and social benefits [5,132-134]. In some cases, this may mean that difficult decisions and trade-offs are necessary. However, it is worrying that ocean sustainability is often treated like an end-sum game, where procedural and distributional considerations are less important than taking action to achieve desired outcomes. This paper suggests that both the means and the ends are important. Greater attention to both the processes through which ocean sustainability is pursued and to all three pillars (i.e., ecological, economic and social) of sustainability will pay dividends in our efforts to achieve a sustainable ocean. As policy-makers, managers, practitioners and funders are making decisions about policy creation, management actions, program design or funding priorities in the oceans, they need to also ask "Who should be included in decision-making?" and "How will different groups be impacted by decisions?". Proactive attention to these questions will help to ensure that injustices and exclusions are avoided and do not undermine the 
ocean sustainability agenda. Navigating a just and inclusive path towards sustainable oceans will require significant will and adequate support from policy circles and funding from foundations, governments and multi-lateral funding agencies.

Table 1 -Marine policy realms and actions to promote just and inclusive oceans at different scales

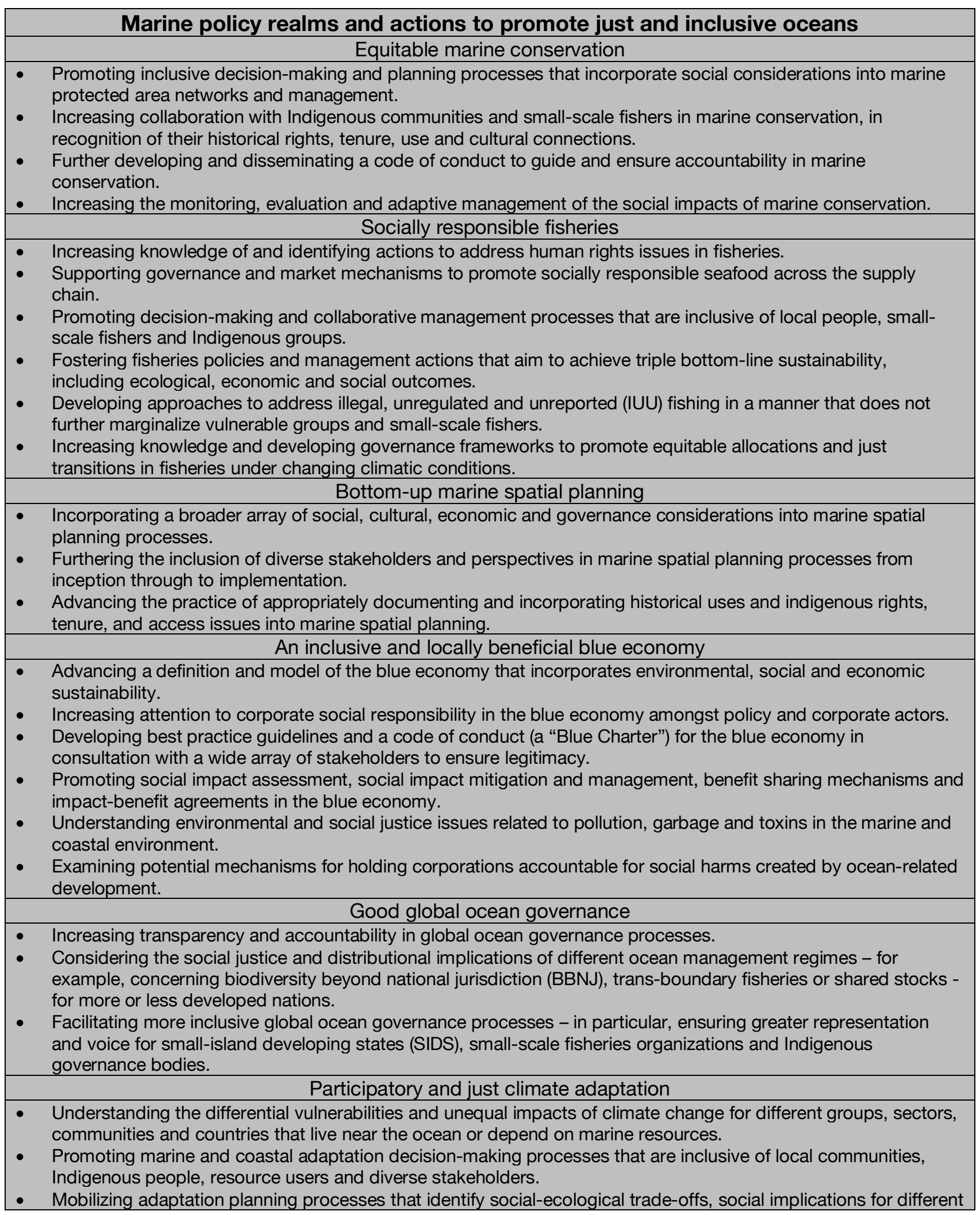


N.Bennett - Navigating a just and inclusive path to sustainable oceans 10

groups, and both short and long time horizons to help identify socially equitable adaptions and avoid maladaptations.

\section{References}

[1] L. Boonzaier, D. Pauly, Marine protection targets: an updated assessment of global progress, Oryx. 50 (2016) 27-35. doi:10.1017/S0030605315000848.

[2] U.R. Sumaila, C. Bellmann, A. Tipping, Fishing for the future: An overview of challenges and opportunities, Mar. Policy. (2016). doi:10.1016/j.marpol.2016.01.003.

[3] W. Swartz, E. Sala, S. Tracey, R. Watson, D. Pauly, The Spatial Expansion and Ecological Footprint of Fisheries (1950 to Present), PLOS ONE. 5 (2010) e15143. doi:10.1371/journal.pone.0015143.

[4] R.A. Watson, W.W.L. Cheung, J.A. Anticamara, R.U. Sumaila, D. Zeller, D. Pauly, Global marine yield halved as fishing intensity redoubles, Fish Fish. (2012) n/a-n/a. doi:10.1111/j.14672979.2012.00483.x.

[5] P. Ehlers, Blue growth and ocean governance- - how to balance the use and the protection of the seas, WMU J. Marit. Aff. (2016) 1-17. doi:10.1007/s13437-016-0104-x.

[6] J.J. Silver, N.J. Gray, L.M. Campbell, L.W. Fairbanks, R.L. Gruby, Blue Economy and Competing Discourses in International Oceans Governance, J. Environ. Dev. (2015). doi:10.1177/1070496515580797.

[7] World Bank, United Nations, The Potential of the Blue Economy: Increasing Long-term Benefits of the Sustainable Use of Marine Resources for Small Island Developing States and Coastal Least Developed Countries, World Bank, Washington, DC, 2017.

[8] S. Jay, W. Flannery, J. Vince, W.-H. Liu, J.G. Xue, M. Matczak, J. Zaucha, H. Janssen, J. van Tatenhove, H. Toonen, A. Morf, E. Olsen, J.L.S. de Vivero, J.C. Rodríguez Mateos, H. Calado, J. Duff, H. Dean, International Progress in Marine Spatial Planning, Ocean Yearb. Online. 27 (2013) 171-212. doi:10.1163/22116001-90000159.

[9] T. Agardy, Ocean Zoning: Making Marine Management More Effective, Earthscan, 2010.

[10] R. Blasiak, J. Pittman, N. Yagi, H. Sugino, Negotiating the use of biodiversity in marine areas beyond national jurisdiction, Mar. Aff. Policy. 3 (2016) 224. doi:10.3389/fmars.2016.00224.

[11] Y.-C. Chang, Ocean Governance: A Way Forward, Springer, New York, 2011.

[12] L.M. Campbell, N.J. Gray, L. Fairbanks, J.J. Silver, R.L. Gruby, B.A. Dubik, X. Basurto, Global Oceans Governance: New and Emerging Issues, Annu. Rev. Environ. Resour. 41 (2016) 517-543. doi:10.1146/annurev-environ-102014-021121.

[13] L.M. Campbell, N.J. Gray, L.W. Fairbanks, J.J. Silver, R.L. Gruby, Oceans at Rio+20, Conserv. Lett. 6 (2013) 439-447. doi:10.1111/conl.12035.

[14] The Economist, World Ocean Summit 2018, Econ. Events. (2018). https:/events.economist.com/events-conferences/americas/world-ocean-summit/ (accessed February 5, 2018).

[15] Future Earth, Home, Future Earth Coasts. (2018). https://www.futureearthcoasts.org/ (accessed February 5, 2018).

[16] Future Earth, Global Research Projects, Future Earth. (2018). http://futureearth.org/projects (accessed February 5, 2018).

[17] Earth System Governance, Taskforce on Ocean Governance, Earth Syst. Gov. (2018). http://www.earthsystemgovernance.net/oceans/ (accessed February 5, 2018).

[18] Future Earth, Future Earth Ocean Knowledge-Action Network, (2018). http://www.futureearth.org/future-earth-ocean (accessed February 21, 2018).

[19] UNESCO, United Nations Decade of Ocean Science for Sustainable Development (2021-2030), U. N. Educ. Sci. Cult. Organ. (2017). https://en.unesco.org/ocean-decade (accessed February 5, 2018). 
[20] M. Visbeck, Ocean science research is key for a sustainable future, Nat. Commun. 9 (2018) 690. doi:10.1038/s41467-018-03158-3.

[21] N.J. Bennett, L. Teh, Y. Ota, P. Christie, A. Ayers, J.C. Day, P. Franks, D. Gill, R.L. Gruby, J.N. Kittinger, J.Z. Koehn, N. Lewis, J. Parks, M. Vierros, T.S. Whitty, A. Wilhelm, K. Wright, J.A. Aburto, E.M. Finkbeiner, C.F. Gaymer, H. Govan, N. Gray, R.M. Jarvis, M. Kaplan-Hallam, T. Satterfield, An appeal for a code of conduct for marine conservation, Mar. Policy. 81 (2017) 411418. doi:10.1016/j.marpol.2017.03.035.

[22] A. Charles, L. Westlund, D.M. Bartley, W.J. Fletcher, S. Garcia, H. Govan, J. Sanders, Fishing livelihoods as key to marine protected areas: insights from the World Parks Congress, Aquat. Conserv. Mar. Freshw. Ecosyst. 26 (2016) 165-184. doi:10.1002/aqc.2648.

[23] P.J.S. Jones, Equity, justice and power issues raised by no-take marine protected area proposals, Mar. Policy. 33 (2009) 759-765. doi:10.1016/j.marpol.2009.02.009.

[24] V.R. Kamat, Dispossession and disenchantment: The micropolitics of marine conservation in southeastern Tanzania, Mar. Policy. 88 (2018) 261-268. doi:10.1016/j.marpol.2017.12.002.

[25] P.H. Sand, Fortress Conservation Trumps Human Rights? The "Marine Protected Area" in the Chagos Archipelago, J. Environ. Dev. 21 (2012) 36-39. doi:10.1177/1070496511435666.

[26] C. Pedersen, T. Feodoroff, R. Reuter, J. Franco, N. Buxton, M.C. Barbesgaard, P. Vervest, The Global Ocean Grab: A Primer, Transnational Institute, Masifundise, Afrika Kontakt and World Forum of Fisher Peoples, 2014.

[27] N.J. Bennett, P. Dearden, Why local people do not support conservation: Community perceptions of marine protected area livelihood impacts, governance and management in Thailand, Mar. Policy. 44 (2014) 107-116. doi:10.1016/j.marpol.2013.08.017.

[28] N. Buxton, C. Pedersen, M.C. Barbesgaard, Ocean grabbing: a new wave of 21 st century enclosures, The Ecologist. (2014).

http://www.theecologist.org/News/news_analysis/2598963/ocean_grabbing_a_new_wave_of_21st century_enclosures.html (accessed December 3, 2014).

[29] M. Cormier-Salem, J. Panfili, Mangrove reforestation: greening or grabbing coastal zones and deltas? Case studies in Senegal, Afr. J. Aquat. Sci. 41 (2016) 89-98. doi:10.2989/16085914.2016.1146122.

[30] N.J. Bennett, H. Govan, T. Satterfield, Ocean grabbing, Mar. Policy. 57 (2015) 61-68. doi:10.1016/j.marpol.2015.03.026.

[31] M. Bavinck, F. Berkes, A. Charles, A.C.E. Dias, N. Doubleday, P. Nayak, M. Sowman, The impact of coastal grabbing on community conservation - a global reconnaissance, Marit. Stud. 16 (2017) 8. doi:10.1186/s40152-017-0062-8.

[32] FAO, Voluntary guidelines for securing sustainable small-scale fisheries in the context of food security and poverty eradication, Food and Agriculture Organization of the United Nations, Rome, 2015. http://www.fao.org/documents/card/en/c/21360061-9b18-42ac-8d78-8a1a7311aef7/ (accessed October 29, 2015).

[33] R. Chuenpagdee, World Small-scale Fisheries: Contemporary Visions, Eburon Uitgeverij B.V., 2011.

[34] R.C.G. Capistrano, A.T. Charles, Indigenous rights and coastal fisheries: A framework of livelihoods, rights and equity, Ocean Coast. Manag. 69 (2012) 200-209. doi:10.1016/j.ocecoaman.2012.08.011.

[35] A. Davis, K. Ruddle, Massaging the Misery: Recent Approaches to Fisheries Governance and the Betrayal of Small-Scale Fisheries, Hum. Organ. 71 (2012) 244-254. doi:10.17730/humo.71.3.205788362x751128. 
N.Bennett - Navigating a just and inclusive path to sustainable oceans 12

[36] C. Chambers, G. Helgadóttir, C. Carothers, "Little kings": community, change and conflict in Icelandic fisheries, Marit. Stud. Heidelb. 16 (2017) 1-26. doi:http://dx.doi.org/10.1186/s40152017-0064-6.

[37] C. Knott, B. Neis, Privatization, financialization and ocean grabbing in New Brunswick herring fisheries and salmon aquaculture, Mar. Policy. 80 (2017) 10-18.

doi:10.1016/j.marpol.2016.10.022.

[38] A. Robertson, T. Sutcliffe, D. Fernandes, B. Reid-Kuecks, J. McIsaac, D. Nobles, L. Moriel, K. Pepper-Smith, D. Brown, M. Mesmain, Caught up in catch shares, Ecotrust Canada and T. Buck Suzuki Environmental Foundation, Vancouver, BC, 2014.

[39] A. Stocks, State of Coastal Communities in British Columbia 2016, T. Buck Suzuki Environmental Foundation, 2016.

[40] H.-K. Hernes, S. Jentoft, K.H. Mikalsen, Fisheries Governance, Social Justice and Participatory Decision-Making, Particip. Fish. Gov. (2005) 103-118. doi:10.1007/1-4020-3778-3 6.

[41] R. Doering, L. Goti, L. Fricke, K. Jantzen, Equity and ITQs: About Fair Distribution in Quota Management Systems in Fisheries, Environ. Values. 25 (2016) 729-749. doi:10.3197/096327116X14736981715742.

[42] E.M. Finkbeiner, N.J. Bennett, T.H. Frawley, J.G. Mason, D.K. Briscoe, C.M. Brooks, C.A. Ng, R. Ourens, K. Seto, S. Switzer Swanson, J. Urteaga, L.B. Crowder, Reconstructing overfishing: Moving beyond Malthus for effective and equitable solutions, Fish Fish. 18 (2017) 1180-1191. doi:10.1111/faf.12245.

[43] S.C. Klain, R. Beveridge, N.J. Bennett, Ecologically sustainable but unjust? Negotiating equity and authority in common-pool marine resource management, Ecol. Soc. 19 (2014) 52. doi:http://dx.doi.org/10.5751/ES-07123-190452.

[44] B.J. McCay, others, ITQs and community: an essay on environmental governance, Agric. Resour. Econ. Rev. 33 (2004) 162-170.

[45] M. Marschke, P. Vandergeest, Slavery scandals: Unpacking labour challenges and policy responses within the off-shore fisheries sector, Mar. Policy. 68 (2016) 39-46. doi:10.1016/j.marpol.2016.02.009.

[46] J.N. Kittinger, L.C.L. Teh, E.H. Allison, N.J. Bennett, L.B. Crowder, E.M. Finkbeiner, C. Hicks, C.G. Scarton, K. Nakamura, Y. Ota, J. Young, A. Alifano, A. Apel, A. Arbib, L. Bishop, M. Boyle, A.M. Cisneros-Montemayor, P. Hunter, E.L. Cornu, M. Levine, R.S. Jones, J.Z. Koehn, M. Marschke, J.G. Mason, F. Micheli, L. McClenachan, C. Opal, J. Peacey, S.H. Peckham, E. Schemmel, V. Solis-Rivera, W. Swartz, T. 'Aulani Wilhelm, Committing to socially responsible seafood, Science. 356 (2017) 912-913. doi:10.1126/science.aam9969.

[47] B.D. Ratner, B. Åsgård, E.H. Allison, Fishing for justice: Human rights, development, and fisheries sector reform, Glob. Environ. Change. 27 (2014) 120-130. doi:10.1016/j.gloenvcha.2014.05.006.

[48] W. Flannery, G. Ellis, G. Ellis, W. Flannery, M. Nursey-Bray, J.P.M. van Tatenhove, C. Kelly, S. Coffen-Smout, R. Fairgrieve, M. Knol, S. Jentoft, D. Bacon, A.M. O'Hagan, Exploring the winners and losers of marine environmental governance/Marine spatial planning: Cui bono?/"More than fishy business": epistemology, integration and conflict in marine spatial planning/Marine spatial planning: power and scaping/Surely not all planning is evil?/Marine spatial planning: a Canadian perspective/Maritime spatial planning - "ad utilitatem omnium"/Marine spatial planning: "it is better to be on the train than being hit by it"/Reflections from the perspective of recreational anglers and boats for hire/Maritime spatial planning and marine renewable energy, Plan. Theory Pract. 17 (2016) 121-151. doi:10.1080/14649357.2015.1131482.

[49] P.J.S. Jones, L.M. Lieberknecht, W. Qiu, Marine spatial planning in reality: Introduction to case studies and discussion of findings, Mar. Policy. 71 (2016) 256-264. doi:10.1016/j.marpol.2016.04.026. 
N.Bennett - Navigating a just and inclusive path to sustainable oceans 13

[50] W. Flannery, N. Healy, M. Luna, Exclusion and non-participation in Marine Spatial Planning, Mar. Policy. 88 (2018) 32-40. doi:10.1016/j.marpol.2017.11.001.

[51] E.L. Cornu, J.N. Kittinger, J.Z. Koehn, E.M. Finkbeiner, L.B. Crowder, Current Practice and Future Prospects for Social Data in Coastal and Ocean Planning, Conserv. Biol. 28 (2014) 902911. doi:10.1111/cobi.12310.

[52] M. Barbesgaard, Blue growth: savior or ocean grabbing?, J. Peasant Stud. (2017) 1-20. doi:10.1080/03066150.2017.1377186.

[53] The Economist Intelligence Unit, The blue economy: Growth, opportunity and a sustainable ocean economy, The Economist Intelligence Unit Ltd, London, 2015.

[54] M.R. Keen, A.-M. Schwarz, L. Wini-Simeon, Towards defining the Blue Economy: Practical lessons from pacific ocean governance, Mar. Policy. (2017) in press. doi:10.1016/j.marpol.2017.03.002.

[55] I. Ertör, M. Ortega-Cerdà, Political lessons from early warnings: Marine finfish aquaculture conflicts in Europe, Mar. Policy. 51 (2015) 202-210. doi:10.1016/j.marpol.2014.07.018.

[56] S.W. Hoefle, Fishing Livelihoods, Seashore Tourism, and Industrial Development in Coastal Rio de Janeiro: Conflict, Multi-Functionality, and Juxtaposition, Geogr. Res. 52 (2014) 198-211. doi:10.1111/1745-5871.12061.

[57] S.C. Stonich, J.R. Bort, L.L. Ovares, Globalization of shrimp mariculture: The impact on social justice and environmental quality in central America, Soc. Nat. Resour. 10 (1997) 161-179. doi:10.1080/08941929709381016.

[58] J. Page, Salmon Farming in First Nations' Territories: A Case of Environmental Injustice on Canada's West Coast, Local Environ. 12 (2007) 613-626. doi:10.1080/13549830701657349.

[59] Z.A. Meletis, L.M. Campbell, Benevolent and Benign? Using Environmental Justice to Investigate Waste-related Impacts of Ecotourism in Destination Communities, Antipode. 41 (2009) 741-780. doi:10.1111/j.1467-8330.2009.00696.x.

[60] S. Cole, A political ecology of water equity and tourism: A Case Study From Bali, Ann. Tour. Res. 39 (2012) 1221-1241. doi:10.1016/j.annals.2012.01.003.

[61] A. Adusah-Karikari, Black gold in Ghana: Changing livelihoods for women in communities affected by oil production, Extr. Ind. Soc. 2 (2015) 24-32. doi:10.1016/j.exis.2014.10.006.

[62] R. Hannesson, The Privatization of the Oceans, MIT Press, 2004.

[63] B. Mansfield, Privatization: Property and the Remaking of Nature-Society Relations, John Wiley \& Sons, 2009.

[64] S. Tuler, J. Agyeman, P.P. da Silva, K.R. LoRusso, R. Kay, Assessing vulnerabilities: Integrating information about driving forces that affect risks and resilience in fishing communities, Hum. Ecol. Rev. 15 (2008) 171-184.

[65] N.J. Bennett, J. Blythe, S. Tyler, N.C. Ban, Communities and change in the anthropocene: understanding social-ecological vulnerability and planning adaptations to multiple interacting exposures, Reg. Environ. Change. (2015) online. doi:10.1007/s10113-015-0839-5.

[66] V. Savo, C. Morton, D. Lepofsky, Impacts of climate change for coastal fishers and implications for fisheries, Fish Fish. (2017) n/a-n/a. doi:10.1111/faf.12212.

[67] U.R. Sumaila, W.W.L. Cheung, V.W.Y. Lam, D. Pauly, S. Herrick, Climate change impacts on the biophysics and economics of world fisheries, Nat. Clim. Change. 1 (2011) 449-456. doi:10.1038/nclimate1301.

[68] R.D. Hardy, R.A. Milligan, N. Heynen, Racial coastal formation: The environmental injustice of colorblind adaptation planning for sea-level rise, Geoforum. 87 (2017) 62-72. doi:10.1016/j.geoforum.2017.10.005. 
N.Bennett - Navigating a just and inclusive path to sustainable oceans 14

[69] I. Ajibade, Can a future city enhance urban resilience and sustainability? A political ecology analysis of Eko Atlantic city, Nigeria, Int. J. Disaster Risk Reduct. 26 (2017) 85-92. doi:10.1016/j.ijdrr.2017.09.029.

[70] E.M. Finkbeiner, F. Micheli, N. J. Bennett, A. L. Ayers, E. Le Cornu, A. N. Doerr, Exploring trade-offs in climate change response in the context of Pacific Island fisheries, Mar. Policy. 88 (2018) 359-364. doi:10.1016/j.marpol.2017.09.032.

[71] M. Bunce, K. Brown, S. Rosendo, Policy misfits, climate change and cross-scale vulnerability in coastal Africa: how development projects undermine resilience, Environ. Sci. Policy. 13 (2010) 485-497. doi:10.1016/j.envsci.2010.06.003.

[72] A. Aseeva, A(n) (Im)Possibility of Justice in the Case of Conservation of Marine Biodiversity of Areas Beyond National Jurisdiction, Social Science Research Network, Rochester, NY, 2017. https://papers.ssrn.com/abstract=2943963 (accessed August 29, 2017).

[73] B. Campbell, Q. Hanich, Principles and practice for the equitable governance of transboundary natural resources: cross-cutting lessons for marine fisheries management, Marit. Stud. 14 (2015) 120. doi:10.1186/s40152-015-0028-7.

[74] CBD, Aichi Biodiversity Targets, Conv. Biol. Divers. (2010). http://www.cbd.int/sp/targets (accessed March 23, 2013).

[75] U. Pascual, J. Phelps, E. Garmendia, K. Brown, E. Corbera, A. Martin, E. Gomez-Baggethun, R. Muradian, Social equity matters in payments for ecosystem services, BioScience. 64 (2014) 10271036. doi:10.1093/biosci/biu146.

[76] K. Schreckenberg, P. Franks, A. Martin, B. Lang, Unpacking equity for protected area conservation, Parks. 22 (2016) 11-26.

[77] N. Zafra-Calvo, U. Pascual, D. Brockington, B. Coolsaet, J.A. Cortes-Vazquez, N. Gross-Camp, I. Palomo, N.D. Burgess, Towards an indicator system to assess equitable management in protected areas, Biol. Conserv. 211, Part A (2017) 134-141. doi:10.1016/j.biocon.2017.05.014.

[78] M. Lockwood, Good governance for terrestrial protected areas: A framework, principles and performance outcomes, J. Environ. Manage. 91 (2010) 754-766. doi:10.1016/j.jenvman.2009.10.005.

[79] J.L. Anderson, C.M. Anderson, J. Chu, J. Meredith, F. Asche, G. Sylvia, M.D. Smith, D. Anggraeni, R. Arthur, A. Guttormsen, J.K. McCluney, T. Ward, W. Akpalu, H. Eggert, J. Flores, M.A. Freeman, D.S. Holland, G. Knapp, M. Kobayashi, S. Larkin, K. MacLauchlin, K. Schnier, M. Soboil, S. Tveteras, H. Uchida, D. Valderrama, The Fishery Performance Indicators: A Management Tool for Triple Bottom Line Outcomes, PLoS ONE. 10 (2015) e0122809. doi:10.1371/journal.pone.0122809.

[80] R.L. Stephenson, A.J. Benson, K. Brooks, A. Charles, P. Degnbol, C.M. Dichmont, M. Kraan, S. Pascoe, S.D. Paul, A. Rindorf, M. Wiber, Practical steps toward integrating economic, social and institutional elements in fisheries policy and management, ICES J. Mar. Sci. (2017) online. doi:10.1093/icesjms/fsx057.

[81] FAO, ed., Voluntary guidelines on the responsible governance of tenure of land, fisheries and forests in the context of national food security, Food and Agriculture Organization of the United Nations, Rome, 2012.

[82] FAO, Code of Conduct for Responsible Fisheries, Food and Agriculture Organization of the United Nations, Rome, 1995. http://www.fao.org/docrep/005/v9878e/v9878e00.htm\#112 (accessed October 16, 2015).

[83] ILO, ILO Work in Fishing Convention No.188, International Labour Organization of the United Nations, Geneva, 2007.

[84] C. Ehler, F. Douvere, Marine spatial planning: a step-by-step approach towards ecosystem-based management., Intergovernmental Oceanographic Commission and Man and the Biosphere 
N.Bennett - Navigating a just and inclusive path to sustainable oceans 15

Programme, Paris, 2009. http://www.oceandatapractices.net/handle/11329/209 (accessed

September 1, 2017).

[85] UN, Blue Economy Concept Paper: Rio+20 United Nations Conference on Sustainable

Development, (2012).

https://sustainabledevelopment.un.org/content/documents/2978BEconcept.pdf (accessed February 4, 2018).

[86] J.A. Michel, Rethinking the Oceans: Towards the Blue Economy, Paragon House, 2017.

[87] The Commonwealth Secretariat, "Game changing" Blue Charter to guide nations in sustainable ocean development, Commonw. - News. (2017).

http://thecommonwealth.org/media/news/\%E2\%80\%98game-changing\%E2\%80\%99-blue-charterguide-nations-sustainable-ocean-development (accessed July 13, 2017).

[88] The Commonwealth Secretariat, Proposed Blue Charter top of the agenda, Commonw. - News. (2017). http://thecommonwealth.org/media/news/proposed-blue-charter-top-agenda (accessed February 4, 2018).

[89] United Nations, The Universal Declaration of Human Rights, United Nations General Assembly, Paris, France, 1948.

[90] United Nations, United nations declaration on the rights of indigenous peoples, United Nations, Washington, DC, 2007. http://www.converge.org.nz/pma/DRIPGA.pdf (accessed October 27, 2015).

[91] UNECE, Aarhus Convention on Access to Information, Public Participation in Decision-Making and Access to Justice in Environmental Matters, United Nations Economic Commission for Europe, Aarhus, Denmark, 1998. http://heinonline.org/hol-cgibin/get_pdf.cgi?handle=hein.journals/mistjintl7\&section=22 (accessed September 30, 2016).

[92] United Nations, Sustainable Development Goals, United Nations, New York, 2015. http://www.un.org/sustainabledevelopment/oceans/ (accessed September 29, 2016).

[93] M. Voyer, W. Gladstone, H. Goodall, Obtaining a social licence for MPAs - influences on social acceptability, Mar. Policy. 51 (2015) 260-266. doi:10.1016/j.marpol.2014.09.004.

[94] A. Sundar, Fishing Community Protest Against Ocean Grabbing Highlights Growing Need to Protect Blue Economy, The Wire. (2017). https://thewire.in/197853/fishing-community-protestocean-grabbing-highlights-growing-need-protect-blue-economy/ (accessed January 8, 2018).

[95] WFFP, World Fisheries Day: WFFP denounces "false solutions" to climate change, World Forum Fish. People. (2015). http://worldfishers.org/2015/11/20/world-fisheries-day-wffp-denounces-falsesolutions-to-climate-change/ (accessed December 11, 2015).

[96] P.J.S. Jones, E.M. De Santo, Viewpoint - Is the race for remote, very large marine protected areas (VLMPAs) taking us down the wrong track?, Mar. Policy. 73 (2016) 231-234. doi:10.1016/j.marpol.2016.08.015.

[97] T. Pullar-Strecker, Maori fisheries trust takes Crown to High Court over Kermadec ocean sanctuary, Stuff N. Z. (2016). http://www.stuff.co.nz/environment/78060924/maori-fisheries-trusttakes-crown-to-high-court-over-kermadec-ocean-sanctuary (accessed May 31, 2016).

[98] O.B.L. affairs correspondent S. Jones, UN ruling raises hope of return for exiled Chagos islanders, The Guardian. (2015). https://www.theguardian.com/world/2015/mar/19/un-ruling-raises-hope-ofreturn-for-exiled-chagos-islanders (accessed December 2, 2016).

[99] P.H. Sand, Fortress Conservation Trumps Human Rights? The "Marine Protected Area" in the Chagos Archipelago, J. Environ. Dev. 21 (2012) 36-39. doi:10.1177/1070496511435666.

[100] C.C. Hicks, A. Levine, A. Agrawal, X. Basurto, S.J. Breslow, C. Carothers, S. Charnley, S. Coulthard, N. Dolsak, J. Donatuto, C. Garcia-Quijano, M.B. Mascia, K. Norman, M.R. Poe, T. Satterfield, K.S. Martin, P.S. Levin, Engage key social concepts for sustainability, Science. 352 (2016) 38-40. doi:10.1126/science.aad4977. 
[101] S. Charnley, C. Carothers, T. Satterfield, A. Levine, M.R. Poe, K. Norman, J. Donatuto, S.J. Breslow, M.B. Mascia, P.S. Levin, X. Basurto, C.C. Hicks, C. García-Quijano, K. St. Martin, Evaluating the best available social science for natural resource management decision-making, Environ. Sci. Policy. 73 (2017) 80-88. doi:10.1016/j.envsci.2017.04.002.

[102] P. Christie, N.J. Bennett, N.J. Gray, T. 'Aulani Wilhelm, N. Lewis, J. Parks, N.C. Ban, R.L. Gruby, L. Gordon, J. Day, S. Taei, A.M. Friedlander, Why people matter in ocean governance: Incorporating human dimensions into large-scale marine protected areas, Mar. Policy. 84 (2017) 273-284. doi:10.1016/j.marpol.2017.08.002.

[103] N.C. Ban, M. Mills, J. Tam, C.C. Hicks, S. Klain, N. Stoeckl, M.C. Bottrill, J. Levine, R.L. Pressey, T. Satterfield, K.M. Chan, A social-ecological approach to conservation planning: embedding social considerations, Front. Ecol. Environ. 11 (2013) 194-202. doi:10.1890/110205.

[104] J.N. Kittinger, J.Z. Koehn, E. Le Cornu, N.C. Ban, M. Gopnik, M. Armsby, C. Brooks, M.H. Carr, J.E. Cinner, A. Cravens, M. D’Iorio, A. Erickson, E.M. Finkbeiner, M.M. Foley, R. Fujita, S. Gelcich, K.S. Martin, E. Prahler, D.R. Reineman, J. Shackeroff, C. White, M.R. Caldwell, L.B. Crowder, A practical approach for putting people in ecosystem-based ocean planning, Front. Ecol. Environ. 12 (2014) 448-456. doi:10.1890/130267.

[105] J.Z. Koehn, D.R. Reineman, J.N. Kittinger, Progress and promise in spatial human dimensions research for ecosystem-based ocean planning, Mar. Policy. 42 (2013) 31-38. doi:10.1016/j.marpol.2013.01.015.

[106] N.J. Bennett, R. Roth, S.C. Klain, K.M.A. Chan, P. Christie, D.A. Clark, G. Cullman, D. Curran, T.J. Durbin, G. Epstein, A. Greenberg, M.P. Nelson, J. Sandlos, R.C. Stedman, T.L. Teel, R.E.W. Thomas, D. Veríssimo, C. Wyborn, Conservation social science: Understanding and integrating human dimensions to improve conservation, Biol. Conserv. 205 (2017) 93-108.

[107] R. Wynberg, M. Hauck, People, Power, and the Coast: a Conceptual Framework for Understanding and Implementing Benefit Sharing, Ecol. Soc. 19 (2014). doi:10.5751/ES-06250190127.

[108] M.R. Poe, K.C. Norman, P.S. Levin, Cultural Dimensions of Socioecological Systems: Key Connections and Guiding Principles for Conservation in Coastal Environments: Cultural dimensions of coastal conservation, Conserv. Lett. 7 (2014) 166-175. doi:10.1111/conl.12068.

[109] S.C. Klain, K.M.A. Chan, Navigating coastal values: Participatory mapping of ecosystem services for spatial planning, Ecol. Econ. 82 (2012) 104-113. doi:10.1016/j.ecolecon.2012.07.008.

[110] K. Gee, A. Kannen, R. Adlam, C. Brooks, M. Chapman, R. Cormier, C. Fischer, S. Fletcher, M. Gubbins, R. Shucksmith, R. Shellock, Identifying culturally significant areas for marine spatial planning, Ocean Coast. Manag. 136 (2017) 139-147. doi:10.1016/j.ocecoaman.2016.11.026.

[111] P. Franks, K. Schreckenberg, Advancing equity in protected area conservation, IIED, London, UK, 2016.

[112] K. Biedenweg, K. Stiles, K. Wellman, A holistic framework for identifying human wellbeing indicators for marine policy, Mar. Policy. 64 (2016) 31-37. doi:10.1016/j.marpol.2015.11.002.

[113] S.J. Breslow, B. Sojka, R. Barnea, X. Basurto, C. Carothers, S. Charnley, S. Coulthard, N. Dolšak, J. Donatuto, C. García-Quijano, C.C. Hicks, A. Levine, M.B. Mascia, K. Norman, M. Poe, T. Satterfield, K.S. Martin, P.S. Levin, Conceptualizing and operationalizing human wellbeing for ecosystem assessment and management, Environ. Sci. Policy. (n.d.).

doi:10.1016/j.envsci.2016.06.023.

[114] M. Kaplan-Hallam, N.J. Bennett, Adaptive social impact management for conservation and environmental management, Conserv. Biol. (2017) online.

[115] K. Schrekenberg, Social assessment of conservation initiatives: a review of rapid methodologies, International Institute for Environment and Development, London, 2010. 
[116] J.R. Wakefield, K. Myers, Social cost benefit analysis for deep sea minerals mining, Mar. Policy. (2016). doi:10.1016/j.marpol.2016.06.018.

[117] N.L. Hall, J. Hicks, T. Lane, E. Wood, Evaluating Community Engagement and Benefit-Sharing Practices in Australian Wind Farm Development, Case Stud. Environ. (2017). doi:10.1525/cse.2017.000521.

[118] B.S. Halpern, C.J. Klein, C.J. Brown, M. Beger, H.S. Grantham, S. Mangubhai, M. Ruckelshaus, V.J. Tulloch, M. Watts, C. White, H.P. Possingham, Achieving the triple bottom line in the face of inherent trade-offs among social equity, economic return, and conservation, Proc. Natl. Acad. Sci. 110 (2013) 6229-6234. doi:10.1073/pnas.1217689110.

[119] C.J. Brown, G. Althor, B.S. Halpern, M.S. Iftekhar, C.J. Klein, S. Linke, E.C. Pryde, S. Schilizzi, J.E.M. Watson, B. Twohey, H.P. Possingham, Trade-offs in triple-bottom-line outcomes when recovering fisheries, Fish Fish. (n.d.) n/a-n/a. doi:10.1111/faf.12240.

[120] J. Kearney, F. Berkes, A. Charles, E. Pinkerton, M. Wiber, The Role of Participatory Governance and Community-Based Management in Integrated Coastal and Ocean Management in Canada, Coast. Manag. 35 (2007) 79-104. doi:10.1080/10.1080/08920750600970511.

[121] M. Lockwood, J. Davidson, A. Curtis, E. Stratford, R. Griffith, Governance principles for natural resource management, Soc. Nat. Resour. 23 (2010) 986-1001. doi:10.1080/08941920802178214.

[122] Ö. Bodin, Collaborative environmental governance: Achieving collective action in socialecological systems, Science. 357 (2017) eaan1114. doi:10.1126/science.aan1114.

[123] E. Pinkerton, Co-operative management of local fisheries, UBC Press, Vancouver, 1989.

[124] N.K. Dubash, Toward Enabling and Inclusive Global Environmental Governance, J. Environ. Dev. 21 (2012) 48-51. doi:10.1177/1070496511435550.

[125] V.M. Nguyen, N. Young, S.J. Cooke, A roadmap for knowledge exchange and mobilization research in conservation and natural resource management, Conserv. Biol. (2016). doi:10.1111/cobi.12857.

[126] A.T. Bednarek, C. Wyborn, C. Cvitanovic, R. Meyer, R.M. Colvin, P.F.E. Addison, S.L. Close, K. Curran, M. Farooque, E. Goldman, D. Hart, H. Mannix, B. McGreavy, A. Parris, S. Posner, C. Robinson, M. Ryan, P. Leith, Boundary spanning at the science-policy interface: the practitioners' perspectives, Sustain. Sci. (2018) 1-9. doi:10.1007/s11625-018-0550-9.

[127] P. Beier, L.J. Hansen, L. Helbrecht, D. Behar, A How-to Guide for Coproduction of Actionable Science, Conserv. Lett. 10 (2017) 288-296. doi:10.1111/conl.12300.

[128] J. McRuer, M. Zethelius, The difference biocultural "place" makes to community efforts towards sustainable development: Youth participatory action research in a marine protected area of Colombia, Int. Rev. Educ. 63 (2017) 847-870. doi:10.1007/s11159-017-9690-x.

[129] G.G. Page, R.M. Wise, L. Lindenfeld, P. Moug, A. Hodgson, C. Wyborn, I. Fazey, Co-designing transformation research: lessons learned from research on deliberate practices for transformation, Curr. Opin. Environ. Sustain. 20 (2016) 86-92. doi:10.1016/j.cosust.2016.09.001.

[130] S. Aswani, X. Basurto, S. Ferse, M. Glaser, L. Campbell, J.E. Cinner, T. Dalton, L.D. Jenkins, M.L. Miller, R. Pollnac, I. Vaccaro, P. Christie, Marine resource management and conservation in the Anthropocene, Environ. Conserv. (2017) 1-11. doi:10.1017/S0376892917000431.

[131] G. Lhuilier, A Time for Reigning In?, SUMADRA Rep. 74 (2016) 40-43.

[132] G.R. Galland, Fishing responsibly and sustainably, Science. 357 (2017) 558-558. doi:10.1126/science.aao0531.

[133] R. Costanza, The ecological, economic, and social importance of the oceans, Ecol. Econ. 31 (1999) 199-213. doi:10.1016/S0921-8009(99)00079-8.

[134] G.G. Singh, A.M. Cisneros-Montemayor, W. Swartz, W. Cheung, J.A. Guy, T.-A. Kenny, C.J. McOwen, R. Asch, J.L. Geffert, C.C.C. Wabnitz, R. Sumaila, Q. Hanich, Y. Ota, A rapid 
N.Bennett - Navigating a just and inclusive path to sustainable oceans 18 assessment of co-benefits and trade-offs among Sustainable Development Goals, Mar. Policy. (2017). doi:10.1016/j.marpol.2017.05.030. 